\title{
Todos os tradutores o tradutor: literatura e tradução na obra de Julio Cortázar
}

\author{
All translators the translator: literature and translation in Julio Cortázar's work
}

\author{
Janaína de Azevedo Baladão \\ Pontifícia Universidade Católica do Rio Grande do Sul - Porto Alegre, RS, Brasil
} \begin{abstract}
$\diamond$
Resumo: Julio Cortázar, escritor e intelectual argentino, nasceu na Embaixada da Argentina em Bruxelas, em 26 de agosto de 1914, e faleceu em Paris, no dia 12 de fevereiro de 1984. O conjunto de sua produção inclui poesia, contos, ensaios, romances, entrevistas, músicas e uma vasta correspondência. Seguindo uma leitura sistemática de sua obra, é possível perceber a imbricação entre o processo de criação literária do escritor e o ofício de tradutor que exerceu ao longo de sua vida. O presente trabalho, nesse sentido, busca pontuar a importância da tradução para a formação do escritor Julio Cortázar, por meio de análise de sua própria obra, entrevistas, sobretudo as que foram concedidas a Harss (2012), Prego Gadea (1985), González Bermejo (2002) e Picón Garfield (1996), e demais textos críticos e biográficos, nomeadamente, Herráez (2011), Goloboff (1998) e Maturo (2004). Como instrumento metodológico, selecionamos menções a traduções literárias, referências à tradução ou ao ofício de tradutor e textos nos quais encontramos a opinião de Cortázar sobre o ofício de traduzir, relacionando-os entre si, já que parecem fazer parte do que se poderia chamar de uma "constelação de figuras" que se interligam. Os resultados apontam para a constatação da total relevância do ofício tradutório na vida e na obra do escritor.
\end{abstract}

Palavras-chave: Literatura; Tradução; Julio Cortázar; Autor-tradutor

\begin{abstract}
Julio Cortázar, argentine writer and intellectual, was born at the Embassy of Argentine in Brussels on August 26, 1914, and died in Paris on February 12, 1984. His production includes poetry, short stories, essays, novels, interviews, songs and a vast correspondence. Following a systematic reading of his work, it is possible to perceive the interconnections between the writer's process of creation and the job of translator that he practiced throughout his life. The present work, in this sense, seeks to highlight the importance of the translation for the writer Julio Cortázar through an analysis of his own work, interviews, especially those that were granted to Harss (2012), Prego Gadea (1985), González Bermejo (2002) and Picón Garfield (1996), as well as through other critical and biographical texts, namely those by Herráez (2011), Goloboff (1998) and Maturo (2004). As a methodological instrument, we have selected references to literary translations, to the translation or to the job of translator and to texts in which we find Cortázar's opinion on the translation practice, relating them to each other, since they seem to be part of what could be called "constellation of figures" that intertwine. The results point to the realization of the total relevance of the translation practice in the writer's life and work.
\end{abstract}

Keywords: Literature; Translation; Julio Cortázar; Author-translator

\section{Palavras iniciais}

Julio Cortázar pertence a uma extensa família de autores-tradutores, como Cervantes, Voltaire, Baudelaire, Mallarmé, Proust, Machado, Borges, Bioy Casares, Silvina e Victoria Ocampo, Quintana, Drummond, os irmãos Campos, entre muitos outros, que formam um sis- tema tradutório no qual ressoa e se evidencia a matériaprima de seus ofícios: o texto literário. Podemos ir mais adiante: esses e outros autores não apenas contribuíram para a formação de um cânone contemporâneo - que, por si só, abre um leque de interpretações e debates -, como também renovaram a biblioteca nacional ao oferecerem novas possibilidades de leitura a quem não tinha acesso 
- seja por falta de conhecimento do idioma, seja por falta do livro em si - ao original.

A escolha do tema "tradução/tradutor" em alguns contos e relatos cortazarianos pode ser relacionada a uma forma de embrião - como explica Cortázar (2006, p. 155-7) ao teorizar sobre como nasce o conto -, que adquire a forma da vida e se "transforma na semente onde dorme a árvore gigante”. Já que essa árvore irá crescer dentro dos leitores, oferecendo sua sombra à memória, o tema deve sempre ser excepcional/significativo, pois é um ímã, ou seja, "um bom tema atrai todo um sistema de relações conexas, coagula no autor, e mais tarde no leitor, uma imensa quantidade de noções, entrevisões, sentimentos e até ideias que lhe flutuavam virtualmente na memória ou na sensibilidade" (CORTÁZAR, 2006, p. 154).

Este artigo, nesse sentido, propõe-se a analisar a importância da tradução na obra cortazariana, bem como a relevância de Cortázar para a formulação do ofício de tradutor, mostrando a própria imagem da tradução que nos oferece e a fecundidade que pode resultar do cruzamento entre ambos os campos. Postulamos que a tradução, no caso de Cortázar, ocupou um papel importante, tanto no que diz respeito à vida cotidiana, na condição de tradutor ativo, como no que tange à repercussão desse ofício em sua obra literária.

\section{Retrospectiva}

Assim como qualquer ato de escrita, a tradução parte de um terreno específico: o idioma do tradutor; além, obviamente, do contexto histórico-social e cultural ao qual este está inserido. É sabido que o nascimento de Cortázar em Bruxelas foi, como ele mesmo explicou, "um produto do turismo e da diplomacia", devido à missão comercial na Bélgica recebida por seu pai, conforme síntese autobiográfica várias vezes reproduzida em diferentes veículos de comunicação, enviada primeiramente, em 1963, à Graciela Maturo (2004, p. 10), crítica que estabeleceu uma interlocução profícua com Cortázar por meio de cartas. O espanhol não foi a língua principal nos primeiros anos da infância do autor; mesmo com a passagem da família pela Espanha, até voltarem para a Argentina, país de origem dos pais de Cortázar, durante quatro anos a comunicação se deu quase exclusivamente em língua francesa. Surgia, então, desse contato, um estímulo, digamos, para absorver novas culturas e relacioná-las entre si. Mas Cortázar foi além desse conhecimento inicial. O domínio posterior do inglês e do italiano do escritor argentino, associado a noções de russo e de alemão, seria, para Maturo (2004, p. 167, tradução nossa), uma "inata predisposição glótica, [...] relacionada com uma permanente busca do signo em relação ao verbo interior, âmbito da poesia".
Muito provavelmente, como aclarou o próprio Cortázar, venha dessa experiência da infância a predisposição para o ofício de tradutor. De acordo com a biografia de Miguel Herráez (2011), muito antes de publicar seus livros, o escritor argentino já se valia da tradução como meio de sobrevivência para a família. A tradução, na verdade, foi exercendo uma forma de modelação de um estilo literário que buscava, como bem podemos ver em seus primeiros contos, reunidos postumamente.

Observando a partir de um ponto distante no tempo, as escolhas de vida de Cortázar parecem convergir desde o princípio para a formação de um tradutor. Assim como ocorre com muitos outros profissionais até hoje, também há uma intersecção na carreira de professor/tradutor. Aos 23 anos, Cortázar viria a assumir o cargo de professor no Colégio Nacional de San Carlos de Bolívar, cidade localizada a trezentos quilômetros de Buenos Aires. Durante o período em que esteve fora da capital, estudou a gramática alemã, escreveu poemas, contos e romances. Suas primeiras traduções do francês ao espanhol foram publicadas na revista Leoplán, cuja direção cabia a Ramón Sopena e José Blaya Lozano. Recluso, Cortázar passou muito tempo em meio a leituras de livros de autores europeus e norte-americanos, em sua maioria, na língua original, fato não ignorado pelos críticos de sua obra. Ele próprio explicou-se várias vezes sobre o assunto. No emblemático livro de $\operatorname{Harss}^{1}$ (2012, p. 221-222, tradução nossa), disse:

Minha geração [...] foi bastante culpada de dar as costas para Argentina. Éramos muito esnobes, mas a maioria apenas se deu conta desse fato muito tempo depois. Líamos muito pouco os escritores argentinos e nos interessava quase tão somente a literatura inglesa e a francesa; subsidiariamente, a italiana, a norte-americana e a alemã, que líamos em tradução. Estávamos muito presos aos escritores franceses e ingleses, até que, em um dado momento (entre os 25 e os 30 anos), muitos de meus amigos - e eu mesmo - descobrimos bruscamente nossa tradição. Nós sonhávamos com Paris e Londres. Buenos Aires era uma espécie de castigo.

Em meio a essa busca de conhecimento, sem possuir um título universitário mas com uma postura autodidata, foi convidado a lecionar literatura inglesa e francesa na Universidade Nacional de Cuyo, na Província de Mendoza, onde traduziu o poeta romântico inglês William Wordsworth. A partir de então, seu nome começaria a ser vinculado à tradução: em 1945, Robinson Crusoé, de

\footnotetext{
O conjunto de entrevistas formulado por Harss foi considerado o "primeiro minuto do boom" - já que por primeira vez se juntariam nomes como Cortázar, García Márquez, Vargas Llosa, Fuentes, Rulfo, Onetti, Guimarães Rosa, Carpentier, Asturias e Borges.
} 
Daniel Defoe, aparecia com o nome de Cortázar como tradutor na página de crédito. Ao abandonar a docência, voltaria aos bancos escolares para completar formalmente seus estudos, recebendo o título de "Tradutor Público Nacional" em Buenos Aires, com habilitação em francês (1948) e em inglês (1949). Mas precisaria continuar trabalhando para ajudar no sustento de sua mãe e irmã, Dona Herminia ${ }^{2}$ e Ofelia, na época, solteira. Para tanto, além de cumprir meia jornada na Câmara Argentina do Livro, tarefa da qual se desvincularia em 1949, exerceu o ofício de tradutor público em Buenos Aires, associando-se a Zoltan Havas no trabalho de tradução pública em 1951, até viajar para a França. Como diria em carta dirigida à Graciela Maturo (2004, p. 10-1):

De 1946 a 1951, vida portenha, solitária e independente; convencido de ser um solteirão irredutível, amigo de pouca gente, melomaníaco, leitor em tempo integral, cinéfilo, burguesinho cego a tudo o que passava além da esfera do estético. Tradutor público nacional. Grande ofício para uma vida como a minha nesse momento, egoisticamente solitária e independente.

Ao trasladar-se a Paris, estabeleceu com a editora Sudamericana um contrato no qual traduziria obras literárias em troca de rendimentos que seriam destinados à manutenção de sua família. Em 1953, a Universidade de Porto Rico, representada por Francisco Ayala, solicitou a tradução da obra narrativa e ensaística de Edgar Allan Poe. O valor a ser pago fora estipulado em três mil dólares, então, Cortázar e Aurora Bernárdez, ${ }^{3}$ com quem se casaria em Paris no dia 22 de agosto de 1953, fizeram as contas e acharam conveniente mudar-se para a Itália a fim de economizar o valor do aluguel e as despesas diárias, já que, como explicou Cortázar, "um tradutor é como um caracol; vai com sua casinha a todos os lados, com sua máquina de escrever e não necessita estar em um lugar determinado" (HERRÁEZ, 2011, p. 155).

Seguiu-se, então, uma cena comum a muitos tradutores na época: desfizeram-se de seus pertences.

\footnotetext{
2 Como é de conhecimento geral, o pai de Cortázar abandonou a família nos anos 20, e Dona Herminia Descotte, "poliglota, já que falava, além de naturalmente o espanhol, inglês, alemão e francês, e que poderia ter exercido o ofício de tradutora, teve de reduzir essa possibilidade que o domínio de línguas supunha em relação à ascensão em categorias de trabalho a pequenos empregos administrativos" (Herráez, 2011, p. 45, tradução nossa). De acordo com entrevista de Cortázar a Prego Gadea (1985), o gosto pelo estudo de idiomas e pela leitura foi herdado de Dona Herminia, que indicava os livros que considerava adequados à idade do filho, dando-lhe acesso a uma biblioteca que estimulou sobremaneira a imaginação.

3 Aurora Bernárdez traduziu as obras de Calvino (com quem o casal conservava uma fraterna amizade) e de outros grandes escritores, como Jean-Paul Sartre e Lawrence Durrell. Cortázar e ela mantiveram o casamento por 14 anos. Após a morte da última esposa de Cortázar, Carol Dunlop, Aurora voltou a cuidar do ex-marido, já doente. Até 2014, ano de sua morte, Aurora deteve uma parte do espólio do escritor e lançou, de maneira sistemática e criteriosa, materiais inéditos.
}

Venderam a Vespa que usavam como transporte, colocaram seus pertences em um guarda-móveis e se prepararam para uma estadia de seis meses de trabalho e mais dois destinados a um périplo pelas cidades italianas. A jornada de trabalho compreendia o período de nove horas diárias, somando sessenta e sete relatos, a Narração de Arthur Gordon Pym, Eureka e Ensaios e críticas, mais as introduções e as notas do tradutor. Apesar do volume de trabalho, traduzir a obra de Poe "foi uma das coisas que realizou com maior prazer em sua vida, confessaria o escritor anos mais tarde" (HERRÁEZ, 2011, p. 155). Vale ressaltar que, durante a permanência em solo italiano, ainda escreveu alguns poemas e trabalhou em Final do jogo.

Foi em 1954 que se vinculou como tradutor independente à Organização das Nações Unidas para a Educação, a Ciência e a Cultura, a "Mother Unesco", ou simplesmente "Ionesco", como costumava chamar Cortázar (2012b, p. 157), o que lhe possibilitaria não apenas viajar e conhecer novas culturas, como também seguir com sua escritura. Aurora também recebeu um contrato como tradutora após submeter-se ao exame de ingresso. $\mathrm{Na}$ verdade, não poderiam exercer o mesmo encargo de tradutores, conforme previa o regulamento, mas essa irregularidade repetiu-se de maneira indefinida, sem nunca ocorrer nenhuma punição, aliás, essa "situação kafkiana foi motivo de permanente humor e brincadeira entre eles, visto que, apesar de saberem na Unesco que eram casados, continuavam solicitando-os, embora formalmente lhes advertiam de que era algo ilícito" (HERRÁEZ, 2011, p. 161-162).

Em geral, dedicavam seis meses do ano à tarefa de "manter a pureza do idioma espanhol", como diria Cortázar a Harss (2012, p.224). De fato, a opção de traduzir ou não parecia seguir apenas um critério: a necessidade financeira do casal. Por essa razão, meses depois, sem dinheiro, como conta Cortázar a Prego Gadea (1985), viajaria a Montevidéu como enviado da Unesco para a celebração da Conferência Geral, aproveitando para passar por Argentina, de maneira independente. Enquanto os altos funcionários se hospedavam em grandes estabelecimentos novos, na estadia montevideana, Cortázar escolheu o Cervantes, o preferido de Borges e de Gardel, mesmo hotel que se instalaria a personagem Petrone, do conto "A porta condenada", publicado em Final do jogo, em 1959.

Durante a passagem pelo Uruguai, registrou a dura realidade econômica pela qual vinha passando o país ao rememorar o quanto seus amigos tentavam conseguir contratos de tradução para que pudessem ir à Europa. De volta a Paris, trouxe na bagagem a encomenda da editora Sudamericana de traduzir Memórias de Adriano, de Marguerite Yourcenar, que havia lido durante sua viagem 
à Itália. Somado à tarefa pessoal de escrever seus contos, a Unesco lhe ofereceu um projeto de viagem de duração de 18 ou 24 meses, abarcando Suíça, Índia, Espanha (treze cidades percorridas em um mês e meio), Holanda, Bélgica, Portugal, Turquia ou Grécia.

Cortázar traduziu documentos elaborados e assuntos diversos à literatura, "relativos ao trigo, à alfabetização em Moçambique, ao algodão ou às relações consulares, que quase nada o seduziam" (HERRÁEZ, 2011, p.216), como ele próprio aclara em "Translate, traduire, tradurre: traducir":

[...] passei boa parte de meus já copiosos lustros traduzindo livros, certidões de nascimento, patentes, notas consulares e relatórios do diretor geral da Unesco, estes últimos em colaboração com diversos e joviais colegas catalães, equatorianos, argentinos, bascos e galegos. Intérprete silencioso, em minha juventude, vivi tempos prazerosos, enquanto traduzia livros como Mémoires d'Adrien, de Marguerite Yourcenar, ou L'immoraliste, de André Gide, que anos depois paguei com jornadas de horror ou de letargia diante de relatórios de alguns especialistas das Nações Unidas nas esferas (eles escrevem dessa forma) da sociologia/alfabetização/irrigação/meios massivos de comunicação (sic)/biblioteconomia/reatores atômicos de água pesada, etc., que geralmente mereciam sua denominação de "relatórios", mas em uma segunda acepção. (CORTÁZAR, 2006b, p. 560-561, tradução nossa)

Apesar da monotonia, cumpria sua tarefa de maneira competente e responsável, de tal forma que, em 1956, a Unesco lhe ofereceu o posto de tradutor fixo em Paris ou Nova York, oferta esta recusada. Preferiu a função de free lance "mesmo com todas as vantagens que implicava a outra categoria, sobretudo no que diz respeito à segurança financeira" (HERRÁEZ, 2011, p. 216), pois o importante era não ser um "empregado full-time, just a happy free-lance, so help me God!', como diria a Paul Blackburn em carta datada em 1958 (CORTÁZAR, 2012, p. 156). Em suas palavras: "Para que um posto permanente? Suficientemente permanente será a morte um dia" (HERRÁEZ, 2011, p. 216). Em contrapartida, aceitou "o posto de revisor de tradutores, mais cômodo e com uma remuneração mais alta que a de tradutor raso" (HERRÁEZ, 2011, p. 216), que lhe permitiria sobreviver, como declarou a Juan Prat, um ano tranquilamente, com apenas cinco ou seis meses de trabalho de revisão. Dessa experiência, declara:

No dia em que, graças a meus relevantes méritos, passei de tradutor a revisor, nas organizações internacionais, o cotejo de versões de outras pessoas me proporcionou momentos inesquecíveis. Um exemplo que já pertence ao nosso folclore profissional vem do seguinte texto em francês: "Comme disait feu le président Roosevelt, ríen n'est á craindre hormis la crainte elle-méme", que foi alegremente traduzido por: "Como dizia com ardor o presidente Roosevelt, o medo das formigas é criado por elas mesmas". Poderíamos admitir que a versão é mais rica e mais metafísica do que o texto original, fato igualmente perceptível no caso de um relatório sobre bolsas de estudo concedidas pelos Estados Unidos ao México, no qual a expressão Scholarship foi entendida como "um barco carregado de escolares", posto a navegar com grande desenvoltura por páginas e páginas (CORTÁZAR, 2006b, p. 561).

Nos anos 50, sua produção literária publicada não vendia o suficiente para poder sustentar-se sem a tradução, mas "paulatinamente seus contos foram sendo traduzidos e publicados, em francês, italiano, inglês e alemão, para revistas ou livros de antologias" (HERRÁEZ, 2011, p. 169). Os anos 60 viram nascer $O$ jogo da amarelinha, obra que o colocaria no centro de atenção de inúmeros leitores e críticos literários. De acordo com Maturo (2004, p. 11), o "trabalho como tradutor na Unesco condenou-o durante alguns anos a uma vida nômade, da qual às vezes se queixava, mas, no fundo, era afim à sua inquietude permanente". Para Maturo (2004, p. 167), o sucesso de Cortázar como tradutor se deve ao fato de que "o domínio do próprio idioma se acha intimamente ligado ao seu conhecimento de outras línguas que, em vez de subestimar ou desvirtuar sua língua natal, proporciona uma ampliação de suas possibilidades expressivas". Maturo (2004, p.167) acrescenta ainda que os exercícios linguísticos de Cortázar, especialmente em $O$ jogo da amarelinha, "englobam o âmbito das línguas relacionadas com a cultura mediterrânea, sem esquecer a riqueza do idioma". Vale lembrar que "esses exercícios" muitas vezes ocorreram em períodos nos quais estava trabalhando para a Unesco. Em entrevista a Evelyn Picón Garfield (1996, p. 782, tradução nossa), em 1978, Cortázar, ao ser perguntado pelo tipo de ambiente para exercer seu trabalho, disse:

Não tenho muitas manias nem sou muito sistemático, mas tenho de dizer que, à medida que vou envelhecendo, necessito cada vez mais de certas condições. Eu não poderia trabalhar em condições fisicamente incômodas. Por exemplo - isso o Diretor Geral da Unesco não iria gostar de sabê-lo -, muitos capítulos de $O$ jogo da amarelinha e muitos capítulos de 62 foram escritos no escritório entre dois "batches" de traduções, isto é, quando eu estava cansado de meu trabalho colocava uma folha de papel na máquina. Bem, as pessoas circulavam, entravam e saiam. Nas seções de tradução espanhola todos gritam, porque, se os espanhóis não gritam, se afogam. 
Segundo a explanação de Herráez (2011, p. 214-215), o fato de ter livros traduzidos, o recebimento de cartas de leitores, o convite para publicação ou reedição de grandes editoras (como Gallimard, Pantheon Books, Souvenir Press, Penguin, etc.), o aumento no número de tiragem a cada publicação, as adaptações ao cinema de alguns contos, a concessão de prêmios, "não alterou seus vínculos com a Unesco". Quando as provisões terminavam, Julio e Aurora aceitavam os convites da Unesco para novas viagens. Foi assim, depois do investimento em uma casa em Saignon, na França, e sua posterior e urgente reforma. Voltaram a Paris e viajaram até Genebra em seu carro, instalando-se em uma pequena chácara em Nyon, em pleno campo. O ano era 1965. Após um mês de trabalho, Cortázar se dirigiu a Teerã, enquanto Bernárdez ia para Mallorca. Reencontraram-se um mês depois em Viena, onde permaneceram por quatro semanas traduzindo. Em 1968, estavam juntos no Irã, após três meses trabalhando para a UNCTAD, na Índia, como residentes convidados de Octavio Paz, então embaixador do México em Nova Déli. Desse destino, foram a Teerã, dessa vez juntos, e logo à Grécia, para participar de outro congresso sobre algodão, onde se encontraram com Vargas Llosa, também contratado como tradutor e intérprete.

Como expõe Herráez (2011, p. 248), Julio e Aurora compartilharam a vida em Paris e viajaram por quase todo o mundo no ofício de tradutores: entre outros países, conheceram Itália, França, Espanha, Bélgica, Suíça, Holanda, Alemanha, Luxemburgo, Áustria, Cuba, Checoslováquia, Portugal, Turquia, Índia, Hungria, Grã Bretanha, Argélia, Irã, Ceilão, Grécia, até a sua separação. No momento da ruptura com Aurora, Cortázar havia terminado de revisar as provas finais de 62. Modelo de armar e estava trabalhando em Último round. Já era conhecido por Bestiário, Final do jogo, As armas secretas, Histórias de cronópios e de famas, Todos os fogos ofogo, A volta ao dia em oitenta mundos, Os prêmios e Ojogo da amarelinha. Sua obra já havia sido traduzida ao menos a doze idiomas. A última tradução literária é de apenas um ano antes da morte de Cortázar, vitimado pela leucemia em 1984: trata-se do livro Llenos de niños los árboles, de sua última e grande companheira, Carol Dunlop, ${ }^{4}$ falecida no dia 2 de novembro de 1982.

\section{Traduções literárias}

Estimativamente, a obra literária e teórica cortazariana extrapola o volume de suas traduções e, ao adentrarmos o universo de Cortázar, descobrimos que os posicionamentos e reflexões sobre a arte tradutória são

\footnotetext{
4 Carol Dunlop, de origem norte-americana, dominava também o francês, já que havia se radicado no Québec, após participação ativa em lutas sociais e manifestações contra a Guerra do Vietnã (GOLOBOFF, 1998, p. 250).
}

mais escassos, quando comparados a outros temas como a discussão sobre a literatura. Não apenas são raros, mas, em determinados momentos, certos comentários corroboram a ideia de um processo desalentador. Esse pessimismo em relação ao ofício aparece mais nitidamente em Imagem de John Keats:

\begin{abstract}
Traduzir? Sim, usaremos traduções. Mas nós, os tradutores, sabemos que tipo de desalento de destruição e de "mãos sujas" nos espera ao amanhecer, como traduzir se parece a amar, como os pequenos triunfos parciais não consolam da enorme derrota. Et cetera, et cetera. Quero outra coisa. Quero sugerir ao leitor um sistema de substituições eventual, uma matéria semelhante, um eco dessa música original [...]. Can you read English? Então não aprenderá nada novo aqui. Proponho para os hispanoparlantes uma trama de encontros, a cópia de ressonâncias que nasce com cada leitura das Odas, o caramujo completo de meu tempo keatsiano (CORTÁZAR, 2005, p. 991-992, tradução nossa, grifos do autor).
\end{abstract}

Cabe lembrar que essa imagem desoladora que o tradutor faz de si mesmo não é exclusiva de uma época. Marco Lucchesi (2010) compara a tradução a um barco em meio a um naufrágio, no qual o tradutor, na condição de capitão, por dever moral e ético, seria o último a saltar. Nesse sentido, no entender de Lucchesi (2010), a tradução, ou pelo menos a total tradução de um texto a outro, é praticamente impossível, pois, como afirma, "a gente não chega à parte alguma na Terra. É apenas uma tentativa de equilibrar as parcelas de ignorância, que são aquelas possíveis, ou seja, aquelas com as quais a gente pode lidar".

Se a tradução desilude, em outro vértice, ao ser questionado por Ernesto González Bermejo (2002, p. 1920), em 1978, sobre como se daria a passagem da ideia à prosa, Cortázar esclarece que "literatura se faz fazendo literatura", mas também aponta que o fato de ter estudado línguas estrangeiras muito cedo e a fascinação que a tradução lhe causava também foram fatores decisivos para o amadurecimento como escritor. Como textualmente diz:

Se não fosse escritor, seria tradutor. Aliás, fui e ainda sou; às vezes, traduzo para a Unesco. A tradução me fascina como trabalho paraliterário ou literário de segundo grau. Quando uma pessoa traduz, quer dizer, quando não é responsável pelo conteúdo original, seu problema não são as ideias do autor - ele já as colocou ali. O que essa pessoa tem de fazer é traduzilas, e então os valores formais e os valores rítmicos que estão latentes no original passam a ocupar um primeiro plano. Sua responsabilidade é traduzi-los, com as diferenças que existam, de um idioma para o outro. É um exercício extraordinário do ponto de vista rítmico (GONZÁLEZ BERMEJO, 2002, p. 19-20). 
Para Goloboff (1998, p. 115-116, tradução nossa), Cortázar mostrava, acima de tudo, respeito pelo ofício de tradutor, ao mesmo tempo em que valorizava "os aspectos positivos para a atividade literária". Sobre a relação tradução/literatura, Cortázar vai além: "Se eu fosse [...] dar conselhos, diria a um jovem escritor que tenha dificuldades de escrever para deixar de escrever por um tempo por conta própria e passar a traduzir a boa literatura; um dia ele se dará conta de que está escrevendo com uma fluidez que não tinha antes" (GONZÁLEZ BERMEJO, 2002, p. 20).

Protin (2012) analisa alguns aspectos da tradução cortazariana e chega à conclusão de que a economia estilística que aparece na prosa de Cortázar também se reflete em suas traduções literárias. Além do mais, a pesquisadora chama a atenção para o fato de que há uma preocupação em manter a acentuação sóbria do original, ou seja, Cortázar "propõe remontar à origem do original, isto é, acentuar o que era poético de maneira latente" (PROTIN, 2012, tradução nossa). ${ }^{5}$ Em sua apreciação, Protin (2012) encontra determinadas constantes na tradução literária cortazariana, tais como: "coincidência dos textos traduzidos com interesses próprios, importância da voz e do ritmo, pertinência da imagem poética, plasticidade da língua de chegada, grande proximidade literária com o texto inicial". Nesse sentido, de acordo com a pesquisadora, "Cortázar [...] trabalha com propósito de escritor, centrando-se na literalidade de suas traduções" (PROTIN, 2012).

\section{Referências à tradução ou ao ofício de tradutor em sua obra literária}

Ao longo de sua vida, Cortázar fez referência à tradução em seus contos, relatos e ensaios. Não pretendemos abarcar todas as citações de forma exaustiva, mas apenas destacar como a tradução entremeou e teceu a obra cortazariana. Como reafirma Maturo (2004, p. 167): "As traduções às quais se dedicou Cortázar - não apenas por gosto mas também por ofício - [...] permitiram o desenvolvimento de um apuro extraordinário em relação às nuanças da expressão", que, por sua vez, possibilitou "uma versatilidade sintética e uma riqueza semânticofonética, verdadeiramente notáveis, que aplicou em relação à sua própria língua".

\section{1 "Plagios y traducciones"}

Esse é o título do apartado que conforma La otra orilla, obra póstuma que reúne um período de oito anos

\footnotetext{
5 Protin (2012) oferece uma lista de obras traduzidas por Cortázar Vale a pena conferir o artigo. Disponível em: $<$ http://www.mshs.univpoitiers. fr/>.
}

de escrita de Cortázar, de 1937 a 1945. A edição completa ficou à mercê de querelas editoriais até ser publicada pela Alfaguara em 2003. Esse livro, ainda sem tradução ao português, contém os primeiros textos do autor, alguns publicados em "cadernos soltos", divididos em três grandes temáticas: "Plagios y traducciones", "Historia de Gabriel Medrano" e "Prolegómenos a la Astronomía". Em "Plagios y traducciones" temos cinco contos: "El hijo del vampiro", "Las manos que crecen", "Llama el teléfono, Delia", "Profunda siesta de Remi" e "Puzzle".

O primeiro conto, "El hijo del vampiro" (1937), traz à cena o idílio amoroso do vampiro Duggu Van e a humana Lady Vanda, do qual resultará um filho. Em "Las manos que crecen" (1937), as mãos de Plack aumentam desmesuradamente de tamanho, a ponto de precisar arrastá-las ou serem carregadas por outras pessoas. O conto "Llama el teléfono, Delia" (1938) narra a história de Delia e seu filho, e foi publicado em El Despertar de Chivilcoy, assinado com o pseudônimo Julio Denis, em 1941, sem o consentimento do autor, que o considerava "experimental" (GOLOBOFF, 1998, p. 44). Em "Profunda siesta de Remi" (1939), que traz em seu bojo o germe que aparecerá em "Continuidade dos parques", a personagem Remi está imersa em um mundo no qual não difere a realidade da fantasia ao deparar-se com a morte. "Puzzle" (1938), por sua vez, parece também dialogar com "Casa tomada" e "Continuidade dos parques" e vai sugerindo, pouco a pouco, a solução de um grande segredo entre dois irmãos em relação à misteriosa morte de Ralph. De acordo com Lizete Pinho Azevedo (2006, p. 27):

\footnotetext{
"Plagios y traducciones" aponta ironicamente para a proposta de um diálogo com a tradição literária, em que é evidente a relação intertextual estabelecida com motivos e composições narrativas reconhecíveis na história da literatura, mediante uma escritura que se constrói por meio da ressignificação da herança na própria fábula. Velhas lendas de fantasmas, vampiros e bruxas, além de contos de Edgar Allan Poe, Gérard de Nerval e Guy de Maupassant, dialogam com os textos do escritor argentino.
}

E é exatamente essa a questão ao pensarmos na relação com a tradução: uma hipótese de interpretação da escolha do título de "Plagios y traducciones" pelo autor seria o fato de que ele próprio partiu de sua vasta experiência de leitura - de Poe, Nerval, entre outros -, que lia no original. Nesse sentido, como aponta Carmen de Mora (2002, p. 53), "El hijo del vampiro" relacionase com "Ligeia" e "Morella", de Poe; "Las manos que crecen", de acordo com Azevedo (2006, p. 27-29), dialoga com "A mão encantada", de Gérard de Nerval; enquanto, "Puzzle", além de explicitar claramente o nome de Poe no início da narrativa, manifesta relações intertextuais com 
"O coração denunciador", do escritor estadunidense. Em diversas entrevistas, Cortázar revelou sua dívida com os grandes mestres do conto fantástico, sobretudo com Poe, a quem iria traduzir efetivamente, processo que seria decisivo na criação de seu modo de expressão.

\section{2 "Circe"}

Em entrevista a Prego Gadea (1985), Cortázar explica que vários contos de Bestiário, que veio à luz em 1951, funcionaram como uma espécie de autoterapia psicanalítica, principalmente, no que concerne ao conto "Circe". A trama narrativa desse conto gira em torno de Mario, jovem que se apaixona por Delia Mañara, uma moça que cultiva um passado funesto: de alguma forma estava implicada na morte de dois noivos. O primeiro morre em função de uma síncope nervosa; o segundo suicida-se. Avesso às desconfianças da vizinhança, Mario passa a frequentar a casa de Delia e a cortejá-la, até saber o verdadeiro motivo da morte dos antigos apaixonados: eles descobriram tardiamente que Delia oferecia delicados bombons artesanais, que ela mesma passava horas preparando, recheados com o corpo de uma barata.

De acordo com Cortázar, esse conto foi concebido na época em que estava se preparando para obter o título de tradutor público, entre março e abril de 1948; portanto, precisava dedicar-se a "diversas matérias de direito, trabalhos práticos específicos relacionados com a prova em questão e a realização do exame final, escrito e oral, do idioma escolhido. [...] 1948 será lembrado como o ano maldito" (HERRÁEZ, 2011, p. 125-126). A preparação aconteceu em apenas seis meses, o que contrasta em muito com o tempo geral de três anos, "a custa, evidentemente, de um desequilíbrio psíquico que se traduzia em neuroses muito estranhas como a que originou o conto", como explica o próprio Cortázar (PREGO GADEA, 1985, p. 182, tradução nossa). A citação da resposta de Cortázar a Prego Gadea (1985, p. 182-183) é longa, mas vale a pena a leitura:

Eu morava com minha mãe nessa época. Ela cozinhava. Sempre gostei da comida de minha mãe, que merecia toda a minha confiança. De repente, comecei a notar que, ao comer, antes de levar um pedaço à boca, olhava-o cuidadosamente com medo de que houvesse caído uma mosca. Essa atitude me incomodava profundamente porque se repetia de uma maneira nociva. Contudo, como superá-la? [...] Comecei a escrever o conto sem saber o final, como de costume. [...] Terminei-o e, depois de quatro ou cinco dias, de repente, surpreendo-me comendo um puchero em minha casa e cortando uma tortilla. Comendo tudo, como sempre, sem a menor desconfiança. [...] Quantas vezes não comemos uma mosca? E que importância tem isso? Disse a mim mesmo que teria de ter uma explicação. Não aceitei o fato. Isso é algo típico em mim desde criança: não aceitar os fatos dados. E então, prontamente, se estabeleceu o enlace e o final do conto, quando Delia fabrica os bombons com baratas e os dois noivos anteriores se suicidam porque comeram esses bombons e se deram conta do que estava acontecendo. O narrador se salva porque suspeita, abre o bombom, vê a barata e escapa, claro. Acredito que esse é um dos contos mais terríveis que escrevi. Mas significou um exorcismo, porque me curou do temor de encontrar uma barata em minha comida.

\section{3 "Carta a uma senhorita em Paris"}

Esse conto também está incluído em Bestiário e, assim como "Circe", parte de um "exorcismo", ou seja, de uma superação de uma obsessão do autor, dessa vez originada pela falsa ideia de que tinha pelos incomodativos na garganta (GOLOBOFF, 1998, p. 19). Como o próprio título sugere, está escrito em forma de carta, que é dirigida à Andrée. $\mathrm{O}$ remetente mora provisoriamente no apartamento localizado na rua Suipacha, em Buenos Aires, e envia notícias à dona da casa, que está em Paris. O missivista, que é tradutor, vai contando a Andrée como, esporadicamente, vomita um coelhinho e de que forma convive com cada novo animalzinho que nasce.

Sua vida é afetada e seu trabalho, esquecido: para que ninguém descubra o que está acontecendo realmente, evita encontrar-se com seus amigos, desculpando-se com "prolongadas e ineficazes histórias de má saúde, de traduções atrasadas, de evasão" (CORTÁZAR, 1986, p.29). À medida que a situação vai se tornando insustentável (ao final do conto passa a conviver com onze coelhos), não só assiste à destruição do apartamento, como também não consegue terminar seus trabalhos. Assim descreve:

[...] Andrée, as minúcias desventuradas desse amanhecer surdo e vegetal, em que caminho entredormido levantando cabos de trevo, folhas soltas, pelos brancos, aos encontrões nos móveis, louco de sono, e meu Gide que se atrasa. Troyat que não traduzi, e minhas respostas a uma senhora distante que já estará se perguntando se...? Para que continuar tudo isto, para que continuar esta carta que escrevo entre telefones e entrevistas (CORTÁZAR, 1986, p. 30).

No entanto, como adverte Juan Gustavo Cobo Borda (2004, tradução nossa): "O tradutor imaginário talvez se suicide, mas o livro de André Gide, $O$ imoralista, será publicado pela editora Argos de Buenos Aires em 7 de novembro de 1947". De Gide, Cortazár de fato traduziria não apenas $O$ imoralista, como também Assim seja ou os dados estão lançados, publicado pela Sudamericana em 1953. 


\section{4 "As babas do diabo"}

Esse conto faz parte de As armas secretas, lançado em 1959. ${ }^{6}$ Nele, há uma composição de narradores entrelaçados em um jogo que oferece múltiplas conclusões, além de fatos que se abrem a várias perspectivas. Nessa "catarse pela escrita", sempre há uma problematização da linguagem, como explica Cortázar em entrevista à Picón Garfield (1996, p. 779):

Em "As babas do diabo", por exemplo, encontra-se um primeiro problema do escritor que quer expressar algo muito difícil de contar, uma experiência vertiginosa. E se dá conta de que os recursos linguísticos que ele tem ao seu alcance podem trai-lo e podem não servir. Então duvida muito, isso se nota ao começo do conto. Não sabe como deve contá-lo. Começa a contá-lo em primeira pessoa, em terceira, e duvida e vacila.

O narrador-personagem é "Roberto Michel, francochileno, tradutor e fotógrafo amador nas horas vagas" (CORTÁZAR, 1994, p. 62). Está há três semanas "trabalhando na versão para o francês do tratado sobre recusas e recursos de José Norberto Allende, professor da Universidade de Santiago" (CORTÁZAR, 1994, p. 62). Ao encontrar um estranho casal, resolve tirar uma fotografia, que vai ser ampliada diversas vezes, motivo pelo qual "interrompia a toda hora a tradução do tratado [...] para reencontrar o rosto da mulher, as manchas escuras no parapeito" (CORTÁZAR, 1994, p. 70). Como no conto anterior, "Carta a uma senhorita em Paris", aqui também a tradução é posta em segundo plano, ou até mesmo abandonada, depois do desencadeamento de uma situação/objeto que provoca uma distração do plano inicial. A observação fixa da foto acarretaria, portanto, um distanciamento de seu labor tradutório: "A cada tantos minutos, por exemplo, quando não encontrava a maneira de dizer em bom francês o que José Alberto Allende dizia em tão bom espanhol, erguia os olhos e olhava a foto" (CORTÁZAR, 1994, p. 70-71).

Absorvido pelas imagens, o narrador-personagem aproveita para "descansar" da tradução, deixando-se levar pela rememoração: "Então descansava um pouco de meu trabalho e me incluía outra vez com prazer naquela manhã que empapava a foto, recordava ironicamente a imagem colérica da mulher reclamando da fotografia, a fuga ridícula e patética do garoto, a entrada em cena

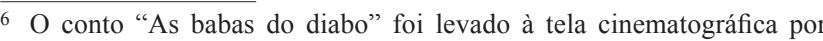
Antonioni com o título de "Blow up". Na etapa de tratativas, em carta a Paul Blackburn, datada em 15 de agosto de 1965, Cortázar (2012, p. 156-157), fala da expectativa do encontro com Antonioni, porque, dependendo do acordo financeiro, seria possível "viver bastante tempo sem trabalhar para a Mother Unesco".
}

do homem do rosto branco" (CORTÁZAR, 1994, p. 71). Outro aspecto a ser mencionado é que, no instante em que tira a foto, altera a trajetória da história narrada. Para Goloboff (1998, p. 115), isso significa dizer que a narração, nesse caso, é uma espécie também de tradução, no sentido de que a atividade do "narrador-tradutor" envolve não apenas a necessidade de encontrar palavras para transpor $\mathrm{o}$ ato fotográfico em narrativa, mas também traduzir a imagem em palavra.

\section{5 "Diário para um conto"}

Publicado dois anos antes de sua morte, em Fora de hora (1982), "Diário para um conto" retoma procedimentos narrativos marcadamente cortazarianos: a metaficção, o ato de narrar e a problematização e o manejo dos recursos da linguagem, além de homenagear outro escritor-tradutor, Bioy Casares. É apresentado em forma de diário, no qual o relato passa a ser construído tal qual uma autobiografia que se mistura a um estilo ensaístico. Como explica Fernanda Andrade Alves (2010, p. 4):

O texto é, portanto, misto de ensaio por causa das indagações do narrador; diário, pelo tom autobiográfico; e conto, pelo viés literário, pelas ilações, pelos pensamentos que vão além do autobiográfico, pelo tratamento estético: construção de um narrador que, embora não seja distante, em terceira pessoa, é uma construção ficcional.

Aqui a tradução funciona de uma maneira inversa em relação aos dois contos anteriores ("Carta a uma senhorita em Paris" e "As babas do diabo"). Na tentativa de iniciar o relato, o narrador se desvia de sua tarefa e traduz um trecho de Derrida, de difícil compreensão, discutindo com o autor como se ele estivesse presente: "como é costume chez Derrida, e o traduzo um pouco como você o criou (mas ele também escreve assim, só que parece que o criaram melhor)" (CORTÁZAR, 1986, p. 148). Nesse relato, o narrador além de tradutor também é escritor de cartas. Localizada nos anos 40, a narrativa gira em torno da vida de Anabel, uma prostituta do Porto que, certo dia, procura o narrador para pedir-lhe que escreva uma carta a um marinheiro (vale ressaltar que a primeira vez que Anabel e o narrador se encontraram ele estava traduzindo uma patente industrial). Desse encontro, estabelece-se uma relação afetuosa, que fracassa quando outra prostituta do Porto é assassinada. O segredo da morte e a implicação de Anabel no crime estão documentados em uma carta escrita pelo narrador, que se sente culpado pela tragédia. Como em outros contos, aqui também vemos a escrita como uma forma de "exorcismo", conforme Cortázar explica: 
O que aconteceu em "Diário para um conto" é muito autobiográfico [...]. Ou pelo menos se pode imaginar que esse conto tem muito de autobiográfico. De fato fui tradutor público em Buenos Aires, onde tive um escritório e traduzi para as prostitutas do Porto as cartas que recebiam de marinheiros de diferentes lugares do mundo. Tinha de traduzir do inglês ao espanhol e logo responder em inglês à pessoa em questão. Como explico no conto, meu sócio me deixou essa herança, e eu a mantive por pena, porque essas moças eram totalmente indefesas em matéria epistolar e em matéria idiomática. Esse é um episódio da minha vida em Buenos Aires que sempre achei curioso, fora do comum. E é verdade também, absolutamente verdade, que numa dessas correspondências eu fiquei sabendo de um crime. Houve uma mulher que desapareceu envenenada. Naturalmente [...], não pedi detalhes, limitei-me a cumprir minha tarefa. No entanto, fiquei sempre com a preocupação de ter sido testemunha epistolar de um episódio muito confuso ocorrido entre pessoas daquele mundo, daquele ambiente. De tudo isso ficou uma espécie de figura dominante, simbólica: a personagem de Anabel. Desde então [...] penso em Anabel. Há três anos, durante umas férias na Martinica, de repente, disse a mim mesmo: "Eu deveria escrever a história de Anabel". E tratei de começar (PREGO GADEA, 1985, p. 38-39).

Cortázar ainda esclarece que, ao tentar contar a história de Anabel, é a personagem que termina por contar a história dele, ou seja, é ela que mostra a "covardia" do narrador diante do crime (PREGO GADEA, 1985, p. 38-39) Além do mais, é justamente a imagem de Anabel que sugere a ação e reflete, em suas palavras, "essa situação ambígua do tradutor, sempre um pouco dividido entre duas coisas, entre idiomas e situações" (PREGO GADEA, 1985, p. 39). Por sua vez, Carlos Fortea (2004, tradução nossa) analisa que o narrador, no papel de "tradutor público diplomado", quando escreve ou traduz para as moças do Porto, em certo momento, passa a "interferir nos textos, a ter liberdades e a modificar o que foi solicitado", dessa forma sai de sua "invisibilidade", nomeadamente quando escreve uma carta identificando-se como tradutor de Anabel. Para Fortea (2004), o "tradutor se apresenta, pois, como um embusteiro, pouco digno de confiabilidade, não resignado a seu papel de cristal" e avesso à fidelidade ao original.

\section{6 "Noite nos ministérios da Europa"}

Esse relato pertence ao "livro-almanaque" A volta ao dia em 80 mundos, de 1967, que une em um mesmo espaço a escrita e a imagem icônica. São crônicas, poesias, contos e ensaios em diálogo com ilustrações de quadros, fotos e desenhos representativos da maneira de pensar do autor. "Noite nos ministérios da Europa" parte da premissa de que um tradutor free lance tem certas liberdades que lhe permite, por exemplo, passar por experiências insólitas, que não seriam plausíveis ou que não fariam parte da realidade de um trabalhador com horários regulares. $\mathrm{O}$ texto, por esse viés, enaltece o fato de que ser um tradutor sem vínculo empregatício pode ser vantajoso, à medida que é possível, por exemplo, conhecer os ministérios da Europa à noite. Aliás, seria possível, nessa condição de tradutor, não apenas decifrar os segredos dos ministérios, como também dos tribunais de justiça, dos palácios legislativos, das dependências oficiais, ou seja, "em geral enormes artefatos de mármore com muitíssimos tapetes e lúgubres funcionários que dependendo do ano e do lugar falam em finlandês, em inglês, em dinamarquês ou farsi" (CORTÁZAR, 2010, p. 115).

Já no início é descrita a sistemática laboral: "as sessões de trabalho se prolongavam até tarde, num país quase desconhecido onde se falavam línguas que desenhavam no ouvido todo tipo de objetos e poliedros incongruentes" (CORTÁZAR, 2010, p. 115). A permissão informal para andar pelas dependências acontecia depois de terminada a jornada diurna, ou, então, quando se era convocado para alguma urgência noturna, já que "sempre havia documentos de última hora para traduzir" (CORTÁZAR, 2010, p. 117). Nesse momento silencioso, enquanto muitos tradutores "preferiam circunscrever-se ao território familiar do escritório [...], os goles de uísque ou de Slivovitz antes da última remessa de documentos urgentes" (CORTÁZAR, 2010, p. 118-119), é que se dá início propriamente à exploração do ambiente.

Esse experimento único, de fato, não apenas serve como estopim para imaginar uma centena de histórias que poderiam ter acontecido naqueles corredores imensos, como também faz com que a imagem desses lugares se misture, "embaralhando até deixar somente um interminável palácio na penumbra" (CORTÁZAR, 2010, p. 121), ou reapareça em sonhos e pesadelos, com a inclusão de quartos, "galerias e escadarias com estátuas pretas", decorados com "bandeiras e salões de luxo e curiosos encontros" (CORTÁZAR, 2010, p. 116-117). Como diz o texto: "Basta talvez a imaginação para entender o privilégio que eram essas passagens pelos ministérios, o fato quase incrível de que um estrangeiro pudesse vagar à meia-noite por recintos aos quais um natural do país jamais teria acesso" (CORTÁZAR, 2010, p. 117).

\section{7 "Não há pior surdo que aquele que"}

Esse é outro relato-ensaio de $A$ volta ao dia $\mathrm{em}$ 80 mundos. Nele, somos convidados a refletir sobre escritores rio-platenses e a língua, enquanto completamos mentalmente o final do provérbio: "Não há pior surdo 
que aquele que não quer ouvir". A crítica do autor incide na influência negativa das "más traduções", quando se pensa na formação do ensino e da literatura rio-platense. De acordo com a linha de raciocínio estabelecida no relato, além da herança do pouco rigor crítico e tradutório que se perpetuou por muitas décadas, o modo de escrita foi afetado diretamente, já que muitos dos novos escritores passaram a "dizer pouco com muito", ou dizê-lo de uma forma inexpressiva (CORTÁZAR, 2010, p. 149). Nas palavras de Cortázar (2010, p.153-154, grifos do autor):

Pensei paralelamente na influência neutralizante e sem vitalidade das traduções no nosso sentimento da língua. Entre 1930 e 1950 o leitor rio-platense leu quatro quintos da literatura mundial contemporânea em traduções, e conheço demais o ofício de tradutor para não saber que ali a língua se retrai a uma função, sobretudo, informativa, e que ao perder sua originalidade se amortecem nela os estímulos eufônicos, rítmicos, cromáticos, escultóricos, estruturais, todo o ouriço do estilo apontando para a sensibilidade do leitor, ferindo-o e estimulando-o pelos olhos, ouvidos, cordas vocais e até pelo sabor, num jogo de ressonâncias e correspondências e adrenalina que entra no sangue para modificar o sistema de reflexos e de respostas e suscitar uma participação porosa nessa experiência vital que é um conto ou um romance. A partir de 1950, o grande público do Rio da Prata descobriu seus escritores e os do resto da América Latina; mas o mal já estava feito e enquanto muitos desses escritores partiam de um instrumento degradado por razões que estou tentando entender, por outro lado os leitores haviam perdido toda exigência e liam um autor uruguaio ou mexicano com a mesma passiva aceitação de signos comunicantes com que vinham lendo Thomas Mann, Alberto Moravia ou François Mauriac em traduções.

Ora, bem sabemos que Cortázar defendia um tipo de "leitor cúmplice", como claramente se vê em $O$ jogo da amarelinha e em outras de suas obras. Esse tipo de "pasteurização" de estilo não lhe interessava. Tendo em vista que a "linguagem deve ser uma preocupação constante do escritor", essas más traduções reduziram "todos os estilos a um denominador comum", influenciando os escritores e provocando uma falsa linguagem e uma abundância de estilos rebuscados (HARSS, 2012, p. 248).

\section{8 "Tombeau de Mallarmé"}

Também pertencente ao livro $A$ volta ao dia em 80 mundos, o poema traduzido "Tombeau", de Stéphane Mallarmé, seguido de um pequeno ensaio, é uma homenagem ao escritor francês do século XIX. Nesse relato, Cortázar (2008, p. 113) enfatiza a tradução poética estabelecendo uma associação com a popular ideia de "tradutor e traidor":

Dos traidores refugiados consuetudinariamente no ofício da tradução, muitos dos que traduzem poesia me parecem avatares daquele Judas sofisticado que trai por inocência e por amor, que abraça sua vítima entre oliveiras e tochas, sob signos de imortalidade e de passagem. Todos os recursos são bons quando no fundo da retorta alquímica brilhará o ouro de que fala Píndaro na primeira Olímpica; por isso se sabe de Judas alquimistas que não vacilam em esconder um grão de ouro no chumbo, simular a transmutação para o príncipe cobiçoso, enquanto continuam a buscá-la solitários e quem sabe a encontram.

A tradução de poesia, por esse ângulo, seria um terreno "equívoco e apaixonado onde se passa da versão à invenção, da paráfrase à palingenesia" (CORTÁZAR, 2008, p. 114), e até mesmo da experiência transcendental de si mesmo a uma tentativa de apagamento do tradutor, que se torna um fantasma na versão final. Nesse triunfo obtido à custa de um alto preço, haveria perdas, ou seja, "a tradução da poesia só se imanta e adquire sentido como os triunfos pírricos ou como o gesto de Jean Borotra já velho deixando a raquete cair e aproximando-se da rede para apertar a mão de seu jovem vencedor que empalidece" (CORTÁZAR, 2008, p. 114).

\section{9 "Inconvenientes nos serviços públicos"}

Publicado em História de cronópios e de famas, que veio à cena em 1962, "Inconvenientes nos serviços públicos" conta a trajetória de um cronópio, que ao ser nomeado diretor-geral de Radiodifusão, chama uma equipe de tradutores da rua San Martín e "os faz traduzir todos os textos, anúncios e canções para o romeno, língua não muito popular na Argentina" (CORTÁZAR, 2007, p. 116). Os famas, ao ouvirem pela manhã seus programas de televisão, ficam assombrados ao escutar tão somente a língua romena. Para contribuir com a confusão geral, aqueles que reclamaram foram atendidos por uma moça que também falava apenas em romeno. O Supremo Governo manda, então, fuzilar o cronópio. Porém, quando tudo parece estar solucionado, um grupo de soldados, formado por cronópios alistados, resiste e atira contra a multidão que está concentrada na Praça de Maio. Apesar da resistência, a sorte do cronópio não dura muito: um pelotão de famas, por fim, fuzila o diretor. Outro fama, autor de canções folclóricas, restabelece o espanhol como idioma nacional. Só que, a essa altura, "os famas haviam perdido a confiança e quase não ligavam os aparelhos" (CORTÁZAR, 2007, p. 116-117). 
Tratado como um relato que denuncia a burocracia do serviço público, esse texto, sem dúvida, coloca o tradutor no centro de uma revolução linguística, que deixa traços significativos: uma parte da população após o episódio passa a desconfiar da informação e resolve aprender o idioma estrangeiro, o que, de fato, faz com que se torne definitiva e paradoxalmente desnecessária a presença do tradutor. Mas não apaga sua figura. Muitos haviam começado a aprender romeno, que virou uma moda nacional, "apesar da cólera do Superior Governo, e ao túmulo do cronópio chegavam furtivamente delegações que deixavam cair lágrimas e cartões de visita" (CORTÁZAR, 2007, p. 117).

\section{Palavras finais}

Nem sempre um autor consagrado tem o talento de ser um grande tradutor, assim como nem sempre um grande escritor tem o engenho de traduzir um bom texto. No caso de Cortázar, sua figura garante um lugar destacado entre ambos os espaços, reservadas as particularidades de cada ofício. Cortázar, sem dúvida, faz parte dessa grande constelação no sistema literáriotradutório, ao estabelecer um complexo sistema de relações. Mas não só isso. Ao pensarmos em Cortázar e em sua geração, mais especificamente, podemos aventar a noção de figuras. Em depoimento a Harss (2012), em 1964, Cortázar retoma a ideia, reiterada ao longo de outras entrevistas, de que, à parte de cada destino individual, somos participantes de um conjunto de figuras em relação às quais não sabemos nada ou quase nada. Em suas palavras: "neste momento podemos estar fazendo parte de uma estrutura que tem continuidade talvez a duzentos metros daqui, onde quem sabe existam outras pessoas que não nos conhecem, assim como nós não as conhecemos" (HARSS, 2012, p. 240). Partindo de um conceito de Cocteau, "segundo o qual as estrelas individuais que formam uma constelação não têm ideia de que fazem parte de uma constelação", Cortázar diz que, assim como as estrelas, talvez nós não saibamos "por que estamos refugiados em nossas individualidades" (HARSS, 2012, p. 240). Por esse ângulo, o ofício de tradutor de Cortázar, tanto no que se refere aos demais tradutores quanto à sua produção crítica e literária, também formaria figuras não tão visíveis, mas que se interligariam à sua existência criativa.

\section{Referências}

ALVES, Fernanda Andrade do Nascimento. A encenação da insuficiência narrativa em "Diário de um conto", de Julio Cortázar. Revista Criação Crítica, São Paulo, n. 4, abr. 2010. Disponível em: <http://www.fflch.usp.br/>. Acesso em: 20 fev. 2017.
AZEVEDO, Lizete Pinho. La otra orilla: espaços no universo criativo dos primeiros contos de Julio Cortázar. 2006. $98 \mathrm{f}$. Dissertação (Mestrado em Letras) - Faculdade de Letras, Fundação Universidade Federal do Rio Grande, Rio Grande, 2006.

COBO BORDA, Juan Gustavo (2004). Julio Cortázar, Traductor. In: Comunidad Andina. Disponível em: <http://www. comunidadandina.org>. Acesso em: 10 jan. 2017.

CORTÁZAR, Julio. Cartas 1955-1964. Edição de Aurora Bernárdez e Carles Álvarez Garriga. Buenos Aires: Alfaguara, 2012.

CORTÁZAR, Julio. Cartas 1965-1968. Edição de Aurora Bernárdez e Carles Álvarez Garriga. Buenos Aires: Alfaguara, 2012b.

CORTÁZAR, Julio. A volta ao dia em oitenta mundos. Tradução de Paulina Wacht e Ariel Roitman. Rio de Janeiro: Civilização Brasileira, 2008, 2010.

CORTÁZAR, Julio. História de cronópios e de famas. Tradução de Gloria Rodríguez. Rio de Janeiro: Civilização Brasileira, 2007.

CORTÁZAR, Julio. Alguns aspectos do conto. In: Valise de cronópio. Tradução de Davi Arriguci Jr. e João A. Barbosa. São Paulo: Perspectiva, 2006.

CORTÁZAR, Julio. Obras completas VI. Obra crítica. Barcelona: Galaxia Gutenberg, 2006b.

CORTÁZAR, Julio. Obras completas IV. Poesía y poética. Barcelona: Galaxia Gutenberg, 2005.

CORTÁZAR, Julio. Obras completas I. Cuentos. Barcelona: Galaxia Gutenberg, 2003.

CORTÁZAR, Julio. As armas secretas. Tradução e prefácio de Eric Nepomuceno. Rio de Janeiro: José Olympio, 1994.

CORTÁZAR, Julio. Fora de hora. Tradução de Remy Gorga, Filho. Rio de Janeiro: Nova Fronteira, 1986.

CORTÁZAR, Julio. Bestiário. Tradução de Olga Savary. Rio de Janeiro: Nova Fronteira, 1985.

FORTEA, Carlos. La perenne continuidad de los parques. $L a$ Jornada Semanal, México, n. 511, 19 dez. 2004. Disponível em: <http://www.jornada.unam.mx/2004/12/19/sem-carlos. html>. Acesso em: 15 jan. 2017.

GOLOBOFF, Mario. Julio Cortázar. La biografía. Buenos Aires: Seix Barral, 1998.

GONZÁLEZ BERMEJO, Ernesto. Conversas com Cortázar. Tradução de Luís Carlos Cabral. Rio de Janeiro: Jorge Zahar, 2002.

HARSS, Luis. Los nuestros. Tradução de Luis Harss. Madri: Santillana, 2012.

HERRÁEZ, Miguel. Julio Cortázar: una biografía revisada. Barcelona: Alrevés, 2011.

LUCCHESI, Marco. Alquimia e tradução. São Paulo: Central de Cursos da UGF, 13 março 2010. Registro de mesa-redonda no I Encontro Internacional de Língua e Tradução.

MATURO, Graciela. Julio Cortázar y el hombre nuevo. Buenos Aires: Fundación Internacional Argentina, 2004. 
MORA, Carmen de. La protohistoria literaria de Cortázar: La otra orilla. In: MANZI, Joaquín (Dir.). La Licorne, Paris, UFR Langues Littératures Poitiers, n. 60, 2002.

PICÓN GARFIELD, Evelyn. Cortázar por Cortázar. In: CORTÁZAR, Julio. Rayuela. Madri, Paris, México, Buenos Aires, São Paulo, Rio de Janeiro: ALLCAXX, 1996.

PREGO GADEA, Omar. La fascinación de las palabras. Conversaciones con Julio Cortázar. Barcelona: Muchninik, 1985.
PROTIN, Sylvie. Del otro lado o el mirar del traductor. Revista on-line Escritural, Écritures d'Amérique Latine, França, março 2012. Disponível em: <http://www.mshs.univ-poitiers.fr/>. Acesso em: 10 dez. 2016.

Recebido: 30 de abril de 2017

Aprovado: 30 de junho de 2017

Contato:

Janaína de Azevedo Baladão <janaina.aguiar@pucrs.br> 